\title{
A microRNA profile of pediatric glioblastoma: The role of NUCKS1 upregulation
}

\author{
LAURA GIUNTI $^{1}$, MARTINA DA ROS ${ }^{2}$, VERONICA DE GREGORIO ${ }^{2}$, ALBERTO MAGI $^{3}$, \\ SAMUELA LANDINI ${ }^{4}$, BENEDETTA MAZZINGHI ${ }^{5}$, ANNA MARIA BUCCOLIERO ${ }^{6}$, \\ LORENZO GENITORI $^{7}$, SABRINA GIGLIO $^{1,4}$ and IACOPO SARDI ${ }^{2}$
}

\begin{abstract}
${ }^{1}$ Medical Genetics Unit, Meyer Children's University Hospital; ${ }^{2}$ Neuro-Oncology Unit, Department of Pediatric Oncology, Meyer Children's University Hospital; ${ }^{3}$ Department of Experimental and Clinical Medicine, University of Florence;

${ }^{4}$ Medical Genetics Unit, Department of Clinical and Experimental Biomedical Sciences 'Mario Serio', University of Florence; ${ }^{5}$ Nephrology and Dialysis, ${ }^{6}$ Pathology and ${ }^{7}$ Neurosurgery Units, Meyer Children's University Hospital, I-50139 Florence, Italy
\end{abstract}

Received June 29, 2018; Accepted December 10, 2018

DOI: $10.3892 /$ mco.2019.1795

\begin{abstract}
MicroRNAs (miRNAs/miRs) are a novel class of gene regulators that may be involved in tumor chemoresistance. Recently, specific miRNA expression profiles have been identified in adult glioblastoma (aGBM), but there are only limited data available on the role of miRNAs in pediatric GBM (pGBM). In the present study, the expression profile of miRNAs was examined in seven pGBMs and three human GBM cell lines (U87MG, A172 and T98G), compared with a non-tumoral pool of pediatric cerebral cortex samples by microarray analysis. A set of differentially expressed miRNAs was identified, including miR-490, miR-876-3p, miR-876-5p, miR-448 and miR-137 (downregulated), as well as miR-501-3p (upregulated). Through bioinformatics analysis, a series of target genes was predicted. In addition, similar gene expression patterns in pGBMs and cell lines was confirmed. Of note, drug resistant $\mathrm{T} 98 \mathrm{G}$ cells had upregulated nuclear casein kinase and cyclin-dependent kinase substrate 1 (NUCKSI) expression, a protein overexpressed in many tumors that serves an important role in cell proliferation and progression. On the basis of the present preliminary report, it could be intriguing to further investigate the relationship between each of the identified differentially expressed miRNAs and NUCKS1, in order to clarify their involvement in the multi-drug resistance mechanism of $\mathrm{pGBMs}$.
\end{abstract}

Correspondence to: Dr Iacopo Sardi, Neuro-Oncology Unit, Department of Pediatric Oncology, Meyer Children's University Hospital, Viale Pieraccini 24, I-50139 Florence, Italy

E-mail: iacopo.sardi@meyer.it

Abbreviations: GBM, glioblastoma multiforme; pGBM, pediatric glioblastoma multiforme; aGBM, adult glioblastoma multiforme; miRNAs, microRNAs

Keywords: microRNAs, gene, glioblastoma multiforme, pediatric brain tumor, high-grade glioma

\section{Introduction}

Glioblastoma (GBM) is a highly aggressive, invasive and poorly responsive brain tumor. At present, the median survival time for children that have received chemotherapy and radiotherapy is reported between 11-24 months; the five-year survival rate is below $20 \%$ (1). Adult (aGBM) and primary pediatric GBM (pGBM) show distinct molecular pathways of tumorigenesis and genetic profiling (1-6); pGBM appears to be more similar to secondary aGBM that has evolved from diffuse grade II or grade III gliomas. Indeed, similarly to secondary aGBM, pGBM exhibits transcriptional regulator ATRX, histone H3.3 and cellular tumor antigen p53 mutations and only rarely shows epidermal growth factor receptor amplification/overexpression $(7,8)$ or phosphatase and tensin homolog mutations $(9)$.

Chemoresistance is the main obstacle to successful chemotherapy for brain tumors. Drug resistance is the main cause of tumor recurrence and patient relapse; this phenomenon is associated with several biological mechanisms, including apoptosis, DNA damage and repair, epigenetic regulation, alteration in ATP-binding cassette transporter family and dysregulation of microRNAs (miRNAs/miRs). A limited number of studies have investigated the underlying mechanisms of pGBM chemoresistance, although in recent decades, increasing amounts of data report the involvement of miRNAs in drug sensitivity and chemoresistance (10-17).

miRNAs represent a novel class of gene regulators that are involved in several physiological processes, including cell differentiation, proliferation, stress response and anti-viral defense, as well as pathological conditions such as cancer (18). They are a large family of evolutionary conserved, short (19-24 nucleotides), single-stranded, non-coding RNAs that also exhibit strong tissue and cellular specificity to developmental stages. They are able to regulate gene expression at the post-transcriptional level, leading to mRNA degradation, with consequential downregulation of encoded protein by translational repression. miRNAs regulate $3 \%$ of the human genome and up to $30 \%$ of protein-coding genes $(19,20)$. Many miRNAs could regulate multiple mRNAs and a single miRNA could regulate multiple mRNA targets (21). 
The etiological role of miRNAs in tumor development is supported by the observation that half of miRNA genes are localized in cancer-associated genes, fragile genome sites (22) or regions that are often amplified (23), acting as tumor suppressors or as oncogenes, depending on which genes/pathways they control (24). Aberrant microRNA expression profiles have been identified in aGBM (25-32), but few studies have investigated the role of miRNAs in pGBM $(33,34)$.

In order to better understand chemoresistance mechanism and regulation in high-grade glioma (HGG), the present study generated a microRNA profile of pGBMs, through a TaqMan ${ }^{\circledR}$ Human MicroRNA Array v2.0 approach. A set of differentially expressed miRNAs in pGBMs and in GBM cell lines (A172, U87MG and resistant-T98G) was identified, in comparison to non-tumor pediatric cerebral cortex samples.

The present preliminary study may contribute the biological understanding of pGBM chemoresistance, which represents the most common causes of relapse (35), and may provide biomarkers for therapeutic strategies.

\section{Materials and methods}

Patients and samples. Patients with pGBM seen between April 2008 and May 2013 at the Meyer Children's University Hospital (Florence, Italy) were eligible for the present study. Histological diagnosis and tumor grading was performed based on the 2007 World Health Organization criteria (36). In total, five non-tumor pediatric cerebral cortex samples (non-tumoral pool) and seven pGBMs were obtained at the Neuro-Surgery Unit of the Meyer Children's University Hospital. The present study was approved by the institutional Ethical Committee. Informed consent was obtained from the parents or legal guardians in all cases. Diagnosis was confirmed by the review of the CNS national panel of pathologists (Umberto I, Policlinico General Hospital Sapienza University, Rome, Italy). The median age at the time of diagnosis was $8 \pm 4.6$ years (age range, 1-15 years; 4 females and 3 males). All patients had been treated with chemotherapy and/or radiotherapy according to consolidated pediatric treatments (37-39) and underwent surgery for resection of disease. The median follow-up was $10 \pm 6.1$ months (range, 3-24 months).

Cell lines. Three human GBM cell lines, A172 (CRL-1620 ATTC, Manassas, VA, USA), U87MG (HTB-14 ${ }^{\mathrm{TM}}$; ATTC) and resistant-T98G (CRL-1690 ${ }^{\mathrm{TM}}$; ATCC) were obtained. U87MG and resistant-T98G were cultured in Eagle's minimum essential medium (Thermo Fisher Scientific, Inc., Waltham, MA, USA), while A172 cells were grown in Dulbecco's modified Eagle's medium (Thermo Fisher Scientific, Inc.). Each medium was supplemented with $10 \%$ fetal bovine serum (cat. no. ECS0180L; EuroClone SpA, Via Figino, Milan, Italy) and $1 \%$ penicillin-streptomycin (Penicillin/Streptomicin 100X; cat. no. ECB3001D; EuroClone SpA). All cell lines were maintained in a humidified atmosphere of $5 \% \mathrm{CO}_{2} / 95 \%$ air at $37^{\circ} \mathrm{C}$. Cells from exponentially growing cultures were used for all experiments.

Expression study. miRNA and mRNA were extracted using the mirVana ${ }^{\mathrm{TM}}$ miRNA Isolation kit (cat. no. AM1560; Thermo Fisher Scientific, Inc.) from tumor (pGBM 1-7) and non-tumor pediatric cerebral cortex samples (pool of 5 samples), as well as pellets of the three cell lines (A172, U87MG and resistant-T98G). Cells were trypsinized (Trypsin-EDTA 1X, cat. no. ECB3052D, Euroclone SpA) from the culture surface (6-well Primo multiwell plate; Euroclone SpA) and transferred to $15 \mathrm{ml}$ conical tubes (TC Tube, $15 \mathrm{ml}$; SARSTEDT AG \& Co. KG, Nümbrecht, Germany). The tubes containing cells and media were centrifuged at $800 \mathrm{x} \mathrm{g}$ for $5 \mathrm{~min}$ at $4^{\circ} \mathrm{C}$ to pellet cells and decant culture media. Subsequently, cells were washed in PBS (cat. no. ECB4004L; EuroClone SpA) and further centrifuged at $800 \mathrm{x}$ g for $5 \mathrm{~min}$ at $4^{\circ} \mathrm{C}$ for pelleting. Finally, PBS was decanted and cell pellets were stored at $-80^{\circ} \mathrm{C}$.

MicroRNA expression profiles of three pGBMs and non-tumoral pool of 5 samples were generated using TaqMan ${ }^{\circledR}$ Human MicroRNA A Cards v2.0 (cat. no. 4398977; Thermo Fisher Scientific, Inc.) according to manufacturers' protocol, using the 7900HT Fast Real-Time PCR system (Thermo Fisher Scientific, Inc.).

Bioinformatic analysis. Raw data were analyzed with the $\mathrm{R}$ computational environment by using the HTqPCR package version 1.0 (40). The package HTqPCR is designed for the analysis of cycle threshold $(\mathrm{Ct})$ values from quantitative PCR (qPCR) data. The heatmap was generated using the $\mathrm{R}$ version 3.5.1 (41) and the HTqPCR package. Raw data were first normalized by using the quantile normalization approach and then analyzed for differential expression with the two-tailed t-test. miRNAs with statistically significant differential expression were analyzed with the miRanda algorithm, (www.microrna.org; version 3.3a) to search for miRNA gene targets (42).

Finally, gene targets were analyzed for enrichment in Gene Ontology (www.geneontology.org) $(43,44)$ and Kyoto Encyclopedia of Genes and Genomes database (www.genome. jp/kegg/kegg1.html) (45-47) with a Fisher's exact test.

Validation of miRNAs by quantitative polymerase chain reaction $(q P C R)$. miRNA was extracted using the mirVana ${ }^{\mathrm{TM}}$ miRNA Isolation kit (cat. no. AM1560; Thermo Fisher Scientific, Inc.) from tumors (pGBM 1-7) and non-tumor pediatric cerebral cortex samples (pool of 5 samples), as well as pellets from three cell lines (A172, U87MG and resistant-T98G). The expression of previously identified dysregulated miRNAs were determined using commercial assays (miR-137, cat. no. 001129; miR-216a, cat. no. 477976; miR-490, cat. no. 001037; miR-501-3p, cat. no. 002435; miR-521, cat. no. Hs99999903_m1; miR-525-3p, cat. no. 478995_mir; miR-873, cat. no. 478204_mir; miR-876-3p, cat. no. 002225; miR-448, cat. no. 001029; all, Thermo Fisher Scientific, Inc.; included forward and reverse primers).

cDNA was synthesized using the TaqMan ${ }^{\circledR}$ MicroRNA Reverse Transcription kit (cat. no. 4366596; Thermo Fisher Scientific, Inc.) according to the manufacturers' protocol $\left(30 \mathrm{~min}\right.$ at $16^{\circ} \mathrm{C}, 30 \mathrm{~min}$ at $42^{\circ} \mathrm{C}$ and $5 \mathrm{~min}$ at $85^{\circ} \mathrm{C}$ ) with the GeneAmp ${ }^{\circledR}$ PCR System 9700-Applied Biosystems (Thermo Fisher Scientific, Inc.).

qPCR was performed using the aforementioned commercial, ready to use assays according to the protocol instructions $\left(10 \mathrm{~min}\right.$ at $95^{\circ} \mathrm{C}, 40$ cycles at $15 \mathrm{sec}$ at $95^{\circ} \mathrm{C}, 60 \mathrm{sec}$ at $60^{\circ} \mathrm{C}$ ) 
Table I. Primer sequences for validation of target genes by SYBR-Green.

\begin{tabular}{|c|c|c|}
\hline Primer & Forward sequence $\left(5^{\prime}-3^{\prime}\right)$ & Reverse sequence $\left(5^{\prime}-3^{\prime}\right)$ \\
\hline GRIA1-EXON13 & AGTCAGCAGAGGCATCAGTT & TGGGTGTTGCAATGCCATAG \\
\hline GRIA1-EXON10 & CGTTACGAGGGCTACTGTGT & TCCATAGACCAGCTCTCCC \\
\hline SORL1-EXON46 & TCACAGCTTACCTTGGGAATACT & GACCCCAGCTCATCGTACAG \\
\hline SORL1-EXON35 & TGGTTGGAGAGAGCATATGGA & GGTCCTCAGGGTCACAAAGT \\
\hline NUCKS1-EXON5 & AAAATGTGCGCCAACAACG & AATGGTGCCTCATCCTCCTC \\
\hline NUCKS1-EXON7 & GTCCAGTGAAAGGCAAAGG & TCAGACCCTTCATCCCCAG \\
\hline SOX11-EXON1 & AATTTCTCTCAAAGCGCGCA & GTGCAGTAGTCGGGGAACT \\
\hline SOX11-EXON1.2 & ACATCAAGCGGCCGATGAA & GGATGAACGGGATCTTCTC \\
\hline SAP30L-EXON1 & GCTTCAGCACGGAGGAGGA & CTTCTGGACCCTCTTGCTGA \\
\hline SAP30L-EXON4 & CGACACTTCAGGAACATACCTG & СCCTCCGATTTCTGGTCCAG \\
\hline HTT-EXON63 & TGTGGGGTGATGCTGTCTG & GTTCACTCTGTCCACACTCA \\
\hline HTT-EXON48 & GTTCAACCTAAGCCTGCTAGC & GGGCTGGAAGACATGATGGA \\
\hline PXMP4-EXON3 & TGCAGGCCACATATATCCACT & CGTGTGCTGGGTAGGTCTT \\
\hline PXMP4-EXON4 & CTGGCTGTAGAGAAGGGCTA & TGTCGTGCCATACATTGCTG \\
\hline THRB-EXON8 & GAGAAAAGACGGCGGGAAGA & CATGGGCTTCGGTGACAGTT \\
\hline THRB-EXON10 & GCGCTATGACCCAGAAAGTG & GGAGGGCTACTTCAGTGTCA \\
\hline PSD3-EXON5 & TCTGAAATGGGGAGCACTGA & TTCTTGCCAAGGTGTTTTGC \\
\hline PSD3-EXON11 & ACTGAGGAGAAAGCTAACGGA & TCTTTCCATCCATATCTGCATGA \\
\hline SPN-EXON2 & СССТАССТСССТСААСТТСС & CTGGTTGCATGAGGGGTTTC \\
\hline SPN-EXON2.1F & GTGACAGTGACCGTGGGAG & GACCCAGACTTCAGCTCCTC \\
\hline AGPAT4-EXON2 & ACCTGGTCTTCTGCTACGTC & AGGACAGTCTGCAGTTGATCT \\
\hline AGPAT4-EXON4 & AAGGTCCTGGCCAAGAAAGA & AAAATACTTCTCGGGGTAGTCC \\
\hline USP31-EXON1 & CTTCATGAACGCCACGCTG & AGCTGCTCAGTGACCTCG \\
\hline USP31-EXON13 & AGACAGGCGCATGAAACTTC & ATGTAGTCCTCAGGGTCCCT \\
\hline GRIK3-EXON3 & CAATGCCGTCCAGTCCATCT & CTGACCGCCACTTGAGGTA \\
\hline GRIK3-EXON14 & TTCGAGAAGATGTGGGCCTT & ATCTGGGTGAGGTTGCAGTT \\
\hline TNRC6B-EXON11 & CCAAATCAAGATGGGTGCCTT & CTAGCAGCGAAGTTTTGGGG \\
\hline TNRC6B-EXON20 & TGGTCCCCAGATCCCATAGG & GATCGGGGTGCTGTGCTG \\
\hline SNX29-EXON5 & CCGTGTTCTGGTACTACGTG & GGAGTGTTCGTTGAGGGCA \\
\hline SNX29-EXON8 & CCAATGGAAGTGAGAGCAGC & СCCTGTGCTTCCTTCCTGAT \\
\hline HIPK2-EXON2 & CGTGCTTGGTCTTCGAGATG & GCGTGGATAAGACCTAGGCT \\
\hline HIPK2-EXON13 & СССТАСТССGАСТССТССА & ACCAATACTTCGCTGGCCT \\
\hline RIMKLA-EXON1 & CAGCTCTGGTTCCTGACGG & GCGATCTGGTCCATAAGCAC \\
\hline RIMKLA-EXON5 & TGACAGAACAAGGCAAGCAG & GCAATGATCCCACCCACATC \\
\hline
\end{tabular}

of the 7900HT Fast Real-Time PCR system (Thermo Fisher Scientific, Inc.). All assays were performed in triplicate. For each miRNA, the expression was normalized to that of RNU48 (cat. no. 001006; Thermo Fisher Scientific, Inc.) and calculated using the $2^{-\Delta \Delta C q}$ method (48). GBMs were subsequently normalized and compared with the non-tumoral pool.

Validation of target genes by SYBR-Green PCR. mRNAs were extracted using the mirVana ${ }^{\mathrm{TM}}$ miRNA Isolation kit (cat. no. AM1560; Thermo Fisher Scientific, Inc.) from tumor (pGBM 1-7) and non-tumor pediatric cerebral cortex (pool of 5 samples) samples, as well as pellets (obtained as aforementioned) of the three cell lines (A172, U87MG and resistant-T98G). cDNA was synthesized using the High Capacity RNA-to-Cdna kit (cat. no. 4387406; Thermo Fisher Scientific, Inc.) according to the manufacturers' protocol $\left(60 \mathrm{~min}\right.$ at $37^{\circ} \mathrm{C}$ and $5 \mathrm{~min}$ at $95^{\circ} \mathrm{C}$ ) with the GeneAmp ${ }^{\circledR} \mathrm{PCR}$ System 9700-Applied Biosystems (Thermo Fisher Scientific, Inc.). Primers were designed using Primer3web version 4.1.0; (http://primer3.ut.ee/). The primer sequences utilized are presented in Table I. Validation of the expression of hypothetical target genes was performed using the LightCycler ${ }^{\circledR}$ 480 SYBR-Green I Master mix (Roche Diagnostics, Basel, Switzerland) on a LightCycler ${ }^{\circledR} 480$ II (Roche Diagnostics) according to the manufacturers' protocol $\left(10 \mathrm{~min}\right.$ at $95^{\circ} \mathrm{C}$, 40 cycles at $15 \mathrm{sec}$ at $95^{\circ} \mathrm{C}, 45 \mathrm{sec}$ at $60^{\circ} \mathrm{C}, 60 \mathrm{sec}$ at $72^{\circ} \mathrm{C}$; melting curve at $10 \mathrm{~min}$ at $95^{\circ} \mathrm{C}, 60 \mathrm{sec}$ at $65^{\circ} \mathrm{C}$ ) and quantification was obtained using $2^{-\Delta \Delta \mathrm{Cq}} \operatorname{method}(48)$.

Statistical analysis. Statistical analysis of nuclear casein kinase and cyclin dependent kinase substrate 1 (NUCKS1) expression was performed using one-way analysis of variance followed 


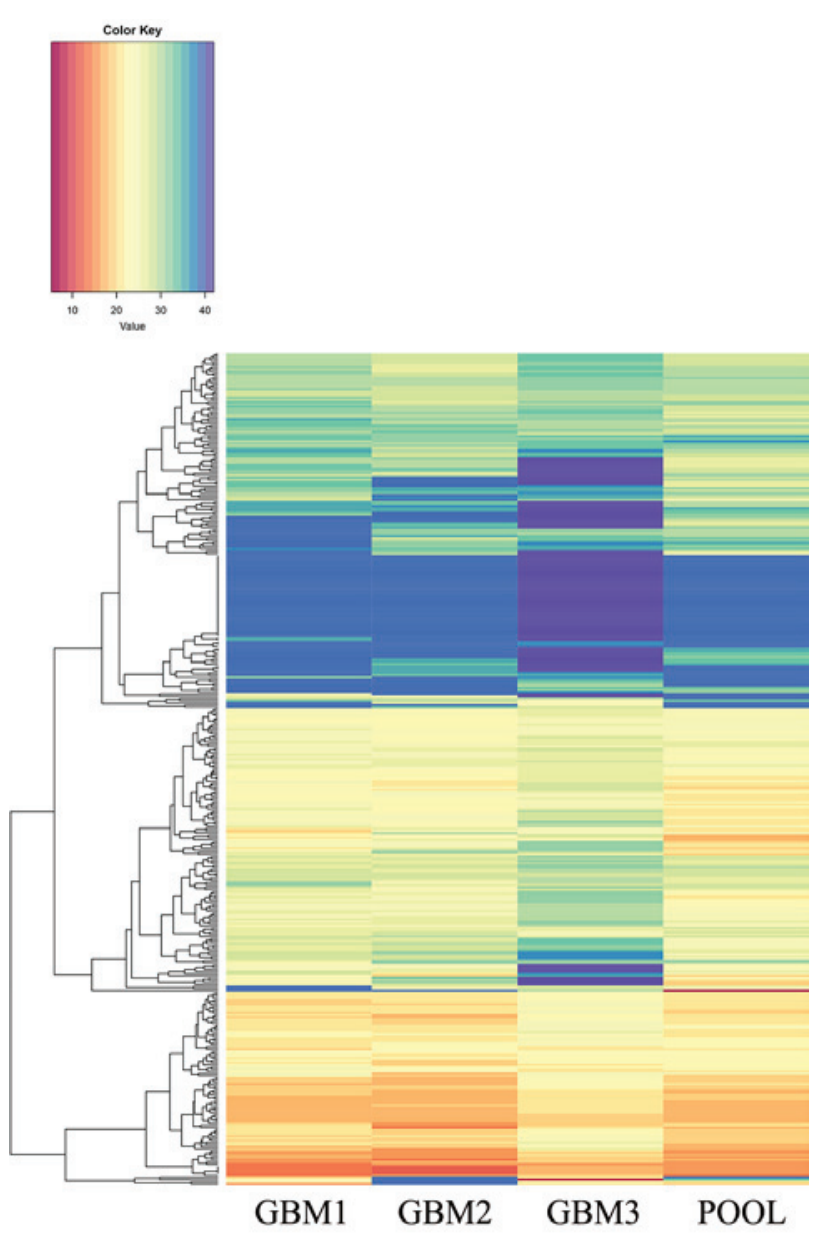

Figure 1. Heatmap of microRNA expression across tumors (GBM1, GBM2 and GBM3) and the non-tumoral control. The color key describes the color associated with each level of expression (0-40 indicates the normalized $\mathrm{Cq}$ values). The heatmap was generated using $\mathrm{R}$ software v3.5.1 and the 'HTqPCR' package. GBM, glioblastoma multiforme; POOL, non-tumoral pool group.

by a Newman-Keuls post hoc test. $\mathrm{P}<0.05$ was considered to indicate a statistically significant difference.

\section{Results}

Bioinformatics analysis. Bioinformatics analysis of TaqMan ${ }^{\circledR}$ Human MicroRNA array version 2.0 revealed a set of miRNAs (miR-137, miR-216a, miR-490, miR-501-3p, miR-521, miR-525-3p, miR-672, miR-873, miR-876-3p and miR-448) that exhibited a statistically significant differential expression in three pGBMs (GBM 1-3) when compared with the non-tumoral pool (Fig. 1; significance cut-off level, two-tailed t-test with $\mathrm{P}<0.01)$.

Validation of miRNAs and target genes. In all tumors (pGBMs 1-7) and GBM cell lines (U87MG, A172 and resistant-T98G), the downregulation of miR-137, miR-490, miR-876-3p, miR-876-5p and miR-448 was confirmed, and the upregulation of miR-501-3p was demonstrated.

Concerning the expression of the other dysregulated miRNAs (miR-216a, -521, -525-3p, -672 and -873), the interpretation of these results were unsuccessful due to poor reaction efficiency of the commercial assays.

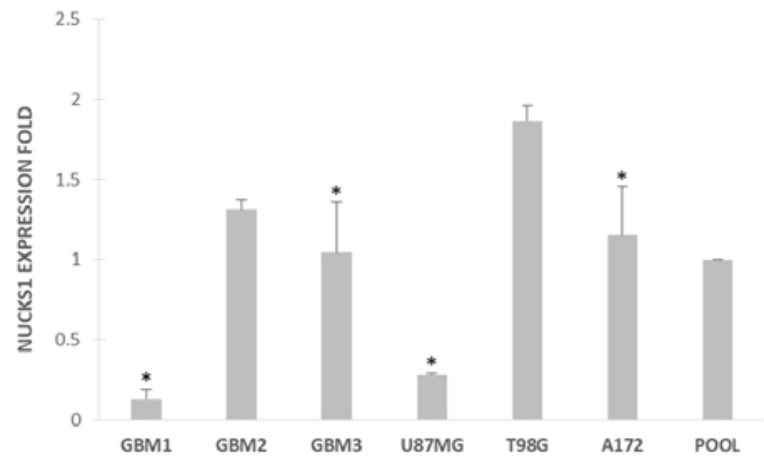

Figure 2. Expression of NUCKS1 in GBMs (GBM1-3) and GBM cell lines (A172, U87MG and resistant-T98G cells). ${ }^{*} \mathrm{P}<0.05$ in the T98G vs. the GBM1, GBM2, GBM3, U87MG and A172 cell lines. GBM, glioblastoma multiforme; NUCKS1, nuclear casein kinase and cyclin dependent kinase substrate 1; POOL, non-tumoral pool group.

The validation of dysregulated miRNA expression was obtained via commercial assays. Moreover, the expression of all following predicted target genes was validated: Glutamate ionotropic receptor AMPA type subunit 1 (GRIAl), sortilin related receptor 1 (SORL1), NUCKS1, SRY-box 11 (SOX11), SAP30 like (SAP30L), huntingtin (HTT), peroxisomal membrane protein 4 (PXMP4), thyroid hormone receptor beta $(T H R B)$, pleckstrin and Sec7 domain containing 3 (PSD3), sialophorin $(S P N), 1$-acylglycerol-3-phosphate O-acyltransferase 4 (AGPAT4), ubiquitin specific peptidase 31 (USP31), glutamate ionotropic receptor kainate type subunit 3 (GRIK3), trinucleotide repeat containing 6B (TNRC6B), sorting nexin 29 (SNX29), homeodomain interacting protein kinase 2 (HIPK2) and ribosomal modification protein rimK like family member A (RIMKLA).

Finally, NUCKS1 was expressed in the tumor tissues and cell lines of the current study. Furthermore, using one-way analysis of variance followed by a Newman-Keuls post hoc test, NUCKS1 expression was compared in T98G vs. GBM1, GBM2, GBM3, U87MG and A172 cell lines. Statistically significant differences were observed $\mathrm{P}<0.05$; Fig. 2) in T98G vs. GBM1, vs. GBM3, vs. U87MG and vs. A172 (all $\mathrm{P}<0.05$; Fig. 2). In particular, NUCKS1 was overexpressed in T98G cells.

\section{Discussion}

In the present study, a microRNA expression profile of pGBM was generated using TaqMan ${ }^{\circledR}$ Human MicroRNA Array v2.0. in GBM tumors (7 pGBMs) and cell lines (U87MG, A172, resistant-T98G). The results demonstrated that miR-137, miR-490, miR-876-3p, miR-876-5p and miR-448 were downregulated, and miR-501-3p was upregulated. Concerning the expression of the other dysregulated miRNAs (miR-216a, -521, $-525-3 p,-672$ and -873), the interpretation of these results was unsuccessful due to the poor reaction efficiency of the commercial assays used.

Furthermore, it was determined that the aforementioned miRNAs were involved in the regulation of the following target genes: GRIA1, SORL1, NUCKS1, SOX11, SAP3OL, HTT, PXMP4, THRB, PSD3, SPN, AGPAT4, USP31, GRIK3, POM121L8P, TNRC6B, SNX29, HIPK2 and RIMKLA. All 
hypothetical target genes were identified in tumors and cell lines and the overexpression of NUCKS1 was detected in drug resistant T98G cells.

NUCKS1 is a highly phosphorylated nuclear DNA-binding protein that is involved in cell cycle progression and proliferation (49). It serves as a substrate for casein kinase 2 and cyclin-dependent kinase (CDK) -1, -2, -4 and -6 (49-53). NUCKS1 also serves a role in the response to DNA damage, homologous recombination and DNA repair mechanisms that are critical for tumor suppression (54). The increased expression of NUCKS1 has been reported in several different types of cancer, including breast, colorectal, cervical and hepatocellular carcinoma (50,55-57). However, its exact role in cancer development remains unclear. The NUCKS1 gene is located on chromosome 1q32.1 (chr 1, 205,712,819-205,750,276), which undergoes recurrent duplication/amplification in several different types of tumor $(58,59)$, including that of the brain (60-63). It is well established that genes amplified in specific copy number variants are associated with tumor progression and poor prognoses (58-63).

Recently, Shen et al (64) demonstrated that NUCKS1 was a target of miR-137 in human lung cancer tissue and resistant lung cell lines. They also revealed that the tumor suppressive role of miR-137 is mediated via the negative regulation of NUCKS1 protein expression. miR-137 is a tumor suppressor and a number of its target genes, including cell division control protein 42, CDK6, cyclooxygenase-2, paxillin, AKT2 and induced myeloid leukemia cell differentiation protein are involved in cancer pathogenesis (64). The loss of miR-137 expression has been determined in several different types of tumor (65-69), including GBMs (28,30,32,69-72). In addition, the restoration of miR-137 expression has been demonstrated to be associated with the inhibition of tumorigenesis (64). In glioma cell lines that overexpress miR-137, cell cycle arrest in the G1 phase is promoted via CDK6 suppression and retinoblastoma-associated protein-1 phosphorylation (26).

miR-137 expression increases during the glioma stem-like cell differentiation in neurosphere cultures (70). The low expression of miR-137 observed in GBM may reflect the loss of tumor cell differentiation, which may contribute to an increased cell proliferation, whilst maintaining an undifferentiated state (70).

At present, few data assess the differential expression of the remaining miRNAs that were determined in the present study. miR-490 is involved in the development and invasion of different types of tumor (73-76) and in the drug resistance of ovarian cancer (77). miR-448 functions as a tumor suppressor gene in osteosarcoma, where it is downregulated in tissues and in vitro models (78). miR-448 is also downregulated in hepatocarcinoma and is associated with tumorigenesis (79). This association has also been reported in ovarian cancer tissues and cell lines (80), breast cancer (81) and in T-cell acute lymphoblastic leukemia (82). Conversely, miR-488 is overexpressed in lung cancer (83).

miR-501-3p has been determined to be a potential biomarker associated with the progression of Alzheimer's disease (84). In cancer however, it may serve as a potential biomarker for pancreatic ductal adenocarcinoma (85) and lymph node metastasis in gastric cancer (86). Additionally, miR-876-3p/5p has been associated with papillary thyroid carcinoma (87),
Hodgkin's lymphoma (88) and lung cancer (89). The miR-876 gene is located on the 9p chromosome, which is deleted in various types of cancer $(90,91)$. Furthermore, pGBMs in particular exhibit a recurrent homozygous or heterozygous 9p21.3 deletion, including the MIR876 gene (60). Thus, the association between each of the dysregulated miRNAs, NUCKS1 overexpression and chemoresistance mechanisms in pGBMs requires further investigation. Furthermore, it may be important to evaluate the role of NUCKS1 protein expression in PGMB tumor progression in a larger and independent group of pediatric high grade glioma samples. NUCKS1 overexpression in the resistant-T98G cell line, in comparison with other non-resistant cell lines, U87MG and A172, indicate its potential involvement in drug sensitivity and pGBM response. The T98G cell line represents a useful in vitro model, which may be utilized to determine the mechanism of acquired chemoresistance in patients with pGBM. In a previous study, it was demonstrated that T98G cells exhibit a different biological response to antineoplastic treatments (doxorubicin) compared with other GBM cell lines (92).

Chemoresistance represents an important challenge in pGBM treatment and overcoming this phenomenon may improve patient prognosis and increase survival rate. miRNAs are promising clinical biomarkers, which may produce a greater understanding of the biological processes associated with the development and progression of pGBMs.

\section{Acknowledgements}

Not applicable.

\section{Funding}

The present study was funded by the Meyer Children's Hospital Anna Meyer Foundation, Florence, Italy.

\section{Availability of data and materials}

The datasets used and/or analyzed during the current study are available from the corresponding author on reasonable request.

\section{Authors' contributions}

LaG designed the current study and analyzed the data. $\mathrm{LaG}$, BM, SL, VDG and MDR performed machine learning analysis. AM interpreted the data. $\mathrm{LaG}$ revised the work critically for important intellectual content. LaG and VDG made substantial contributions to drafting the manuscript. AMB histologically diagnosed the tumors. IS, LoG and SG supervised the study and were involved in patient recruitment, selection and treatment.

\section{Ethics approval and consent to participate}

The present study was approved by the institutional Ethical Committee of Meyer Children's Hospital, Florence, Italy. Informed consent was obtained from the parents or legal guardians in all cases.

\section{Patient consent for publication}

Written informed consent was obtained all the patients. 


\section{Competing interests}

The authors declare that they have no competing interests.

\section{References}

1. Pollack IF, Hamilton RL, James CD, Finkelstein SD, Burnham J, Yates AJ, Holmes EJ, Zhou T and Finlay JL; Children's Oncology Group: Rarity of PTEN deletions and EGFR amplification in malignant gliomas of childhood: Results from the Children's Cancer Group 945 cohort. J Neurosurg 105 (Suppl 5): S418-S424, 2006.

2. Pollack IF, Finkelstein SD, Woods J, Burnham J, Holmes EJ, Hamilton RL, Yates AJ, Boyett JM, Finlay JL and Sposto R; Children's Cancer Group: Expression of p53 and prognosis in children with malignant gliomas. N Engl J Med 346: 420-427, 2002.

3. Pollack IF, Boyett JM, Yates AJ, Burger PC, Gilles FH, Davis RL and Finlay JL; Children's Cancer Group: The influence of central review on outcome associations in childhood malignant gliomas: Results from the CCG-945 experience. Neuro Oncol 5: 197-207, 2003.

4. Ganigi PM, Santosh V, Anandh B, Chandramouli BA and Sastry Kolluri VR: Expression of p53, EGFR, pRb and bcl-2 proteins in pediatric glioblastoma multiforme: A study of 54 patients. Pediatr Neurosurg 41: 292-299, 2005.

5. Nakamura M, Shimada K, Ishida E, Higuchi T, Nakase $H$, Sakaki T and Konishi N: Molecular pathogenesis of pediatric astrocytic tumors. Neuro Oncol 9: 113-123, 2007.

6. Ohgaki H, Dessen P, Jourde B, Horstmann S, Nishikawa T, Di Patre PL, Burkhard C, Schüler D, Probst-Hensch NM, Maiorka PC, et al: Genetic pathways to glioblastoma: A population-based study. Cancer Res 64: 6892-6899, 2004.

7. Di Sapio A, Morra I, Pradotto L, Guido M, Schiffer D and Mauro A: Molecular genetic changes in a series of neuroepithelial tumors of childhood. J Neurooncol 59: 117-122, 2002.

8. Bredel M, Pollack IF, Hamilton RL and James CD: Epidermal growth factor receptor expression and gene amplification in high-grade non-brainstem gliomas of childhood. Clin Cancer Res 5: 1786-1792, 1999.

9. Kraus JA, Felsberg J, Tonn JC, Reifenberger G and Pietsch T: Molecular genetic analysis of the TP53, PTEN, CDKN2A, EGFR, CDK4 and MDM2 tumour-associated genes in supratentorial primitive neuroectodermal tumours and glioblastomas of childhood. Neuropathol Appl Neurobiol 28: 325-333, 2002.

10. He L and Hannon GJ: MicroRNAs: Small RNAs with a big role in gene regulation. Nat Rev Genet 5: 522-531, 2004.

11. Visone R and Croce CM: MiRNAs and cancer. Am J Pathol 174 $1131-1138,2009$

12. Croce CM: Causes and consequences of microRNA dysregulation in cancer. Nat Rev Genet 10: 704-714, 2009.

13. Munoz JL, Walker ND, Scotto KW and Rameshwar P: Temozolomide competes for P-glycoprotein and contributes to chemoresistance in glioblastoma cells. Cancer Lett 367: 69-75, 2015.

14. Sun C, Li N, Yang Z, Zhou B, He Y, Weng D, Fang Y, Wu P, Chen P, Yang X, et al: miR-9 regulation of BRCA1 and ovarian cancer sensitivity to cisplatin and PARP inhibition. J Natl Cancer Inst 105: 1750-1758, 2013

15. Shen R, Wang Y, Wang CX, Yin M, Liu HL, Chen JP, Han JQ and Wang WB: MiRNA-155 mediates TAM resistance by modulating SOCS6-STAT3 signalling pathway in breast cancer. Am J Transl Res 7: 2115-2126, 2015

16. Dong Z, Ren L, Lin L, Li J, Huang Y and Li J: Effect of microRNA-21 on multidrug resistance reversal in A549/DDP human lung cancer cells. Mol Med Rep 11: 682-690, 2015.

17. Blower PE, Chung JH, Verducci JS, Lin S, Park JK, Dai Z, Liu CG, Schmittgen TD, Reinhold WC, Croce CM, et al: MicroRNAs modulate the chemosensitivity of tumor cells. Mol Cancer Ther 7: 1-9, 2008

18. Bartel DP: MicroRNAs: Genomics, biogenesis, mechanism, and function. Cell 116: 281-297, 2004.

19. González-Gómez P, Sánchez P and Mira H: MicroRNAs as regulators of neural stem cell-related pathways in glioblastoma multiforme. Mol Neurobiol 44: 235-249, 2011.

20. Berindan-Neagoe I, Monroig Pdel C, Pasculli B and Calin GA: MicroRNAome genome: A treasure for cancer diagnosis and therapy. CA Cancer J Clin 64: 311-336, 2014.
21. Rajewsky N and Socci ND: Computational identification of microRNA targets. Dev Biol 267: 529-535, 2004.

22. Hummel R, Maurer J and Haier J: MicroRNAs in brain tumors: A new diagnostic and therapeutic perspective? Mol Neurobiol 44: 223-234, 2011.

23. Calin GA, Sevignani C, Dumitru CD, Hyslop T, Noch E, Yendamuri S, Shimizu M, Rattan S, Bullrich F, Negrini M and Croce CM: Human microRNA genes are frequently located at fragile sites and genomic regions involved in cancers. Proc Natl Acad Sci USA 101: 2999-3004, 2004.

24. Fabbri M, Ivan M, Cimmino A, Negrini M and Calin GA Regulatory mechanisms of microRNAs involvement in cancer. Expert Opin Biol Ther 7: 1009-1019, 2007.

25. Møller HG, Rasmussen AP, Andersen HH, Johnsen KB, Henriksen M and Duroux M: A systematic review of microRNA in glioblastoma multiforme: Micro-modulators in the mesenchymal mode of migration and invasion. Mol Neurobiol 47: 131-144, 2013.

26. Shea A, Harish V, Afzal Z, Chijioke J, Kedir H, Dusmatova S, Roy A, Ramalinga M, Harris B, Blancato J, et al: MicroRNAs in glioblastoma multiforme pathogenesis and therapeutics. Cancer Med 5: 1917-1946, 2016

27. Ahir BK, Ozer H, Engelhard HH and Lakka SS: MicroRNAs in glioblastoma pathogenesis and therapy: A comprehensive review. Crit Rev Oncol Hematol 120: 22-33, 2017.

28. Ciafrè SA, Galardi S, Mangiola A, Ferracin M, Liu CG, Sabatino G, Negrini M, Maira G, Croce CM and Farace MG: Extensive modulation of a set of microRNAs in primary glioblastoma. Biochem Biophys Res Commun 334: 1351-1358, 2005.

29. Chan JA, Krichevsky AM and Kosik KS: MicroRNA-21 is an antiapoptotic factor in human glioblastoma cells. Cancer Res 65 : 6029-6033, 2005

30. Silber J, Lim DA, Petritsch C, Persson AI, Maunakea AK, Yu M, Vandenberg SR, Ginzinger DG, James CD, Costello JF, et al: miR-124 and miR-137 inhibit proliferation of glioblastoma multiforme cells and induce differentiation of brain tumor stem cells. BMC Med 6: 14, 2008.

31. Godlewski J, Nowicki MO, Bronisz A, Williams S, Otsuki A, Nuovo G, Raychaudhury A, Newton HB, Chiocca EA and Lawler S: Targeting of the Bmi-1 oncogene/stem cell renewal factor by microRNA-128 inhibits glioma proliferation and self-renewal. Cancer Res 68: 9125-9130, 2008.

32. Lawler S and Chiocca EA: Emerging functions of microRNAs in glioblastoma. J Neurooncol 92: 297-306, 2009.

33. Birks DK, Barton VN, Donson AM, Handler MH, Vibhakar R and Foreman NK: Survey of MicroRNA expression in pediatric brain tumors. Pediatr Blood Cancer 56: 211-216, 2011

34. Miele E, Buttarelli FR, Arcella A, Begalli F, Garg N, Silvano M, Po A, Baldi C, Carissimo G, Antonelli M, et al: High-throughput microRNA profiling of pediatric high-grade gliomas. Neuro Oncol 16: 228-240, 2014.

35. Braunstein S, Raleigh D, Bindra R, Mueller S and Haas-Kogan D: Pediatric high-grade glioma: Current molecular landscape and therapeutic approaches. J Neurooncol 134: 541-549, 2017.

36. Louis DN, Ohgaki H, Wiestler OD, Cavenee WK, Burger PC Jouvet A, Scheithauer BW and Kleihues P: The 2007 WHO classification of tumours of the central nervous system. Acta Neuropathol 114: 97-109, 2007.

37. Stupp R, Mason WP, van den Bent MJ, Weller M, Fisher B, Taphoorn MJ, Belanger K, Brandes A A, Marosi C, Bogdahn U, et al: Radiotherapy plus concomitant and adjuvant temozolomide for glioblastoma. N Engl J Med 352: 987-996, 2005.

38. Massimino M, Gandola L, Luksch R, Spreafico F, Riva D, Solero C, Giangaspero F, Locatelli F, Podda M, Bozzi F, et al: Sequential chemotherapy, high-dose thiotepa, circulating progenitor cell rescue and radiotherapy for childhood high-grade glioma. Neuro Oncol 7: 41-48, 2005.

39. Biassoni V, Casanova M, Spreafico F, Gandola L and Massimino M: A case of relapsing glioblastoma multiforme responding to vinorelbine. J Neurooncol 80: 195-201, 2006.

40. Dvinge $\mathrm{H}$ and Bertone P: HTqPCR: High-throughput analysis and visualization of quantitative real-time PCR data in $R$. Bioinformatics 25: 3325-3326, 2009.

41. R Development Core Team R: A language and environment for statistical computing. R Foundation for Statistical Computing, Vienna, Austria. ISBN 3-900051-07-0, URL http://www.R-project.org., 2008.

42. Enright AJ, John B, Gaul U, Tuschl T, Sander C and Marks DS: MicroRNA targets in drosophila. Genome Biol 5: R1, 2003. 
43. Ashburner M, Ball CA, Blake JA, Botstein D, Butler H, Cherry JM, Davis AP, Dolinski K, Dwight SS, Eppig JT, et al: Gene ontology: Tool for the unification of biology. The Gene Ontology Consortium. Nat Genet 25: 25-29, 2000.

44. The Gene Ontology Consortium: Expansion of the gene ontology knowledgebase and resources. Nucleic Acids Res 45: D331-D338, 2017.

45. Kanehisa M, Furumichi M, Tanabe M, Sato Y and Morishima K: KEGG: New perspectives on genomes, pathways, diseases and drugs. Nucleic Acids Res 45: D353-D361, 2017.

46. Kanehisa M, Sato Y, Kawashima M, Furumichi M and Tanabe M: KEGG as a reference resource for gene and protein annotation. Nucleic Acids Res 44: D457-D462, 2016.

47. Kanehisa M and Goto S: KEGG: Kyoto encyclopedia of genes and genomes. Nucleic Acids Res 28: 27-30, 2000.

48. Livak KJ and Schmittgen TD: Analysis of relative gene expression data using real-time quantitative PCR and the 2(-Delta Delta C(T)) method. Methods 25: 402-408, 2001.

49. Whitfield ML, Sherlock G, Saldanha AJ, Murray JI, Ball CA, Alexander KE, Matese JC, Perou CM, Hurt MM, Brown PO and Botstein D: Identification of genes periodically expressed in the human cell cycle and their expression in tumors. Mol Biol Cell 13: 1977-2000, 2002.

50. Drosos Y, Kouloukoussa M, Østvold AC, Grundt K, Goutas N Vlachodimitropoulos D, Havaki S, Kollia P, Kittas C, Marinos E and Aleporou-Marinou V: NUCKS overexpression in breast cancer. Cancer Cell Int 9: 19, 2009.

51. Walaas SI, Ostvold AC and Laland SG: Phosphorylation of P1, a high mobility group-like protein, catalyzed by casein kinase II, protein kinase C, cyclic AMP-dependent protein kinase and calcium/calmodulin-dependent protein kinase II. FEBS Lett 258 : 106-108, 1989.

52. Ostvold AC, Norum JH, Mathiesen S, Wanvik B, Sefland I and Grundt K: Molecular cloning of a mammalian nuclear phosphoprotein NUCKS, which serves as a substrate for Cdk1 in vivo. Eur J Biochem 268: 2430-2440, 2001.

53. Meijer L, Ostvold AC, Walass SI, Lund T and Laland SG: High-mobility-group proteins $\mathrm{P} 1, \mathrm{I}$ and $\mathrm{Y}$ as substrates of the M-phase-specific p34cdc2/cyclincdc13 kinase. Eur J Biochem 196: 557-567, 1991

54. Parplys AC, Zhao W, Sharma N, Groesser T, Liang F, Maranon DG Leung SG, Grundt K, Dray E, Idate R, et al: NUCKS1 is a novel RAD51AP1 paralog important for homologous recombination and genome stability. Nucleic Acids Res 43: 9817-9834, 2015.

55. Kikuchi A, Ishikawa T, Mogushi K, Ishiguro M, Iida S, Mizushima H, Uetake H, Tanaka $\mathrm{H}$ and Sugihara K: Identification of NUCKS1 as a colorectal cancer prognostic marker through integrated expression and copy number analysis. Int J Cancer 132: 2295-2302, 2013.

56. Gu L, Xia B, Zhong L, Ma Y, Liu L, Yang L and Lou G: NUCKS1 overexpression is a novel biomarker for recurrence-free survival in cervical squamous cell carcinoma. Tumour Biol 35: 7831-7836, 2014.

57. Cheong JY, Kim YB, Woo JH, Kim DK, Yeo M, Yang SJ, Yang KS, Soon SK, Wang HJ, Kim BW, et al: Identification of NUCKS1 as a putative oncogene and immunodiagnostic marker of hepatocellular carcinoma. Gene 584: 47-53, 2016.

58. Balcárková J, Urbánková H, Scudla V, Holzerová M, Bacovský J, Indrák $\mathrm{K}$ and Jarosová M: Gain of chromosome arm 1q in patients in relapse and progression of multiple myeloma. Cancer Genet Cytogenet 192: 68-72, 2009.

59. Szponar A, Zubakov D, Pawlak J, Jauch A and Kovacs G: Three genetic developmental stages of papillary renal cell tumors: Duplication of chromosome 1q marks fatal progression. Int J Cancer 124: 2071-2076, 2009.

60. GiuntiL,PantaleoM,Sardi I,Provenzano A,Magi A,Cardellicchio S, Castiglione F, Tattini L, Novara F, Buccoliero AM, et al Genome-wide copy number analysis in pediatric glioblastoma multiforme. Am J Cancer Res 4: 293-303, 2014

61. Faria C, Miguéns J, Antunes JL, Salgado D, Nunes S, Barroso C, Martins Mdo C, Nunes VM and Roque L: Pediatric brain tumors: Geneticsandclinicaloutcome.JNeurosurgPediatr5:263-270,2010

62. Hirose Y, Aldape K, Bollen A, James CD, Brat D, Lamborn K, Berger $M$ and Feuerstein BG: Chromosomal abnormalities subdivide ependymal tumors into clinically relevant groups. Am J Pathol 158: 1137-1143, 2001.

63. Lo KC, Ma C, Bundy BN, Pomeroy SL, Eberhart CG and Cowell JK: Gain of 1q is a potential univariate negative prognostic marker for survival in medulloblastoma. Clin Cancer Res 13: 7022-7028, 2007.
64. Shen H, Wang L, Ge X, Jiang CF, Shi ZM, Li DM, Liu WT, Yu X and Shu YQ: MicroRNA-137 inhibits tumor growth and sensitizes chemosensitivity to paclitaxel and cisplatin in lung cancer. Oncotarget 7: 20728-20742, 2016.

65. Yang Y, Li F, Saha MN, Abdi J, Qiu L and Chang H: miR-137 and miR-197 induce apoptosis and suppress tumorigenicity by targeting MCL-1 in multiple myeloma. Clin Cancer Res 21: 2399-2411, 2015

66. Liu LL, Lu SX, Li M, Li LZ, Fu J, Hu W, Yang YZ, Luo RZ, Zhang CZ and Yun JP: FoxD3-regulated microRNA-137 suppresses tumour growth and metastasis in human hepatocellular carcinoma by targeting AKT2. Oncotarget 5: 5113-5124, 2014.

67. Chen DL, Wang DS, Wu WJ, Zeng ZL, Luo HY, Qiu MZ, Ren C, Zhang DS, Wang ZQ, Wang FH, et al: Overexpression of paxillin induced by miR-137 suppression promotes tumor progression and metastasis in colorectal cancer. Carcinogenesis 34: 803-811, 2013.

68. Zhu X, Li Y, Shen H, Li H, Long L, Hui L and Xu W: miR-137 inhibits the proliferation of lung cancer cells by targeting $\mathrm{Cdc} 42$ and Cdk6. FEBS Lett 587: 73-81, 2013.

69. Chen L, Wang X, Wang H, Li Y, Yan W, Han L, Zhang K, Zhang J, Wang Y, Feng Y, et al: miR-137 is frequently down-regulated in glioblastoma and is a negative regulator of Cox-2. Eur $\mathrm{J}$ Cancer 48: 3104-3111, 2012.

70. Bier A, Giladi N, Kronfeld N, Lee HK, Cazacu S, Finniss S, Xiang C, Poisson L, deCarvalho AC, Slavin S, et al: MicroRNA-137 is downregulated in glioblastoma and inhibits the stemness of glioma stem cells by targeting RTVP-1. Oncotarget 4: 665-676, 2013.

71. Giunti L, da Ros M, Vinci S, Gelmini S, Iorio AL, Buccoliero AM, Cardellicchio S, Castiglione F, Genitori L, de Martino M, et al: Anti-miR 21 oligonucleotide enhances chemosensitivity of T98G cell line to doxorubicin by inducing apoptosis. Am J Cancer Res 5: 231-242, 2014.

72. Li D, Shan W, Fang Y, Wang P and Li J: miR-137 acts as a tumor suppressor via inhibiting CXCL12 in human glioblastoma. Oncotarget 8: 101262-101270, 2017.

73. Chen W, Ye L, Wen D and Chen F: miR-490-5p inhibits hepatocellular carcinoma cell proliferation, migration and invasion by directly regulating ROBO1. Pathol Oncol Res: Sep 19, 2017 (Epub ahead of print).

74. Xu B, Xu T, Liu H, Min Q, Wang S and Song Q: miR-490-5p suppresses cell proliferation and invasion by targeting BUB1 in hepatocellular carcinoma cells. Pharmacology 100: 269-282, 2017.

75. Tang B, Liu C, Zhang QM and Ni M: Decreased expression of miR-490-3p in osteosarcoma and its clinical significance. Eur Rev Med Pharmacol Sci 21: 246-251, 2017.

76. Li J, Feng Q, Wei X and Yu Y: MicroRNA-490 regulates lung cancer metastasis by targeting poly $\mathrm{r}(\mathrm{C})$-binding protein 1 . Tumour Biol 37: 15221-15228, 2016.

77. Tian J, Xu YY, Li L and Hao Q: miR-490-3p sensitizes ovarian cancer cells to cisplatin by directly targeting ABCC2. Am J Transl Res 9: 1127-1138, 2017.

78. Wu X, Yan L, Liu Y, Xian W, Wang L and Ding X: MicroRNA-448 suppresses osteosarcoma cell proliferation and invasion through targeting EPHA7. PLoS One 12: e0175553, 2017.

79. Zhu H, Zhou X, Ma C, Chang H, Li H, Liu F and Lu J: Low expression of miR-448 induces EMT and promotes invasion by regulating ROCK2 in hepatocellular carcinoma. Cell Physiol Biochem 36: 487-498, 2015

80. Lv Y, Lei Y, Hu Y, Ding W, Zhang C and Fang C: miR-448 negatively regulates ovarian cancer cell growth and metastasis by targeting CXCL12. Clin Transl Oncol 17: 903-909, 2015.

81. Bamodu OA, Huang WC, Lee WH, Wu A, Wang LS, Hsiao M, Yeh CT and Chao TY: Aberrant KDM5B expression promotes aggressive breast cancer through MALAT1 overexpression and downregulation of hsa-miR-448. BMC Cancer 16: 160, 2016.

82. Correia NC, Melão A, Póvoa V, Sarmento L, Gómez de Cedrón M, Malumbres M, Enguita FJ and Barata JT: microRNAs regulate TAL1 expression in T-cell acute lymphoblastic leukemia. Oncotarget 7: 8268-8281, 2016.

83. Powrózek T, Krawczyk P, Kowalski DM, Kuźnar-Kamińska B, Winiarczyk K, Olszyna-Serementa M, Batura-Gabryel H and Milanowski J: Application of plasma circulating microRNA-448, 506,4316 , and 4478 analysis for non-invasive diagnosis of lung cancer. Tumour Biol 37: 2049-2055, 2016.

84. Hara N, Kikuchi M, Miyashita A, Hatsuta H, Saito Y, Kasuga K, Murayama S, Ikeuchi T and Kuwano R: Serum microRNA miR-501-3p as a potential biomarker related to the progression of Alzheimer's disease. Acta Neuropathol Commun 5: 10, 2017. 
85. Ling Q, Xu X, Ye P, Xie H, Gao F, Hu Q, Liu Z, Wei X, Röder C, Trauzold A, et al: The prognostic relevance of primary tumor location in patients undergoing resection for pancreatic ductal adenocarcinoma. Oncotarget 8: 15159-15167, 2017.

86. Jiang X, Wang W, Yang Y, Du L, Yang X, Wang L, Zheng G, Duan W, Wang R, Zhang X, et al: Identification of circulating microRNA signatures as potential noninvasive biomarkers for prediction and prognosis of lymph node metastasis in gastric cancer. Oncotarget 8: 65132-65142, 2017.

87. Huang Y, Liao D, Pan L, Ye R, Li X, Wang S, Ye C and Chen L: Expressions of miRNAs in papillary thyroid carcinoma and their associations with the BRAFV600E mutation. Eur J Endocrinol 168: 675-681, 2013.

88. Paydas S, Acikalin A, Ergin M, Celik H, Yavuz B and Tanriverdi K: Micro-RNA (miRNA) profile in Hodgkin lymphoma: Association between clinical and pathological variables. Med Oncol 33: 34, 2016.

89. Bao L, Lv L, Feng J, Chen Y, Wang X, Han S and Zhao H: miR-876-5p suppresses epithelial-mesenchymal transition of lung cancer by directly down-regulating bone morphogenetic protein 4. J Biosci 42: 671-681, 2017.
90. Riemenschneider MJ, Jeuken JW, Wesseling $\mathrm{P}$ and Reifenberger G: Molecular diagnostics of gliomas: State of the art. Acta Neuropathol 120: 567-584, 2010.

91. Conway C, Beswick S, Elliott F, Chang YM, Randerson-Moor J, Harland M, Affleck P, Marsden J, Sanders DS, Boon A, et al: Deletion at chromosome arm 9p in relation to BRAF/NRAS mutations and prognostic significance for primary melanoma. Genes Chromosomes Cancer 49: 425-438, 2010.

92. Giunti L, da Ros M, Vinci S, Gelmini S, Iorio AL, Buccoliero AM, Cardellicchio S, Castiglione F, Genitori L, de Martino M, et al: Anti-miR21 oligonucleotide enhances chemosensitivity of T98G cell line to doxorubicin by inducing apoptosis. Am J Cancer Res 5: 231-242, 2014.

(i)(9) This work is licensed under a Creative Commons Attribution-NonCommercial-NoDerivatives 4.0 International (CC BY-NC-ND 4.0) License. 